\title{
The exotic species Senecio inaequidens pays the price for arriving late in temperate European grassland communities
}

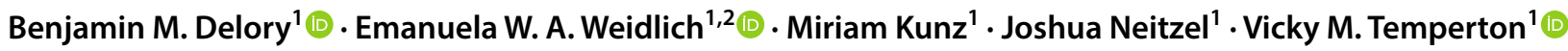

Received: 6 May 2019 / Accepted: 25 September 2019 / Published online: 1 October 2019

(C) The Author(s) 2019

\begin{abstract}
The exotic South African ragwort (Senecio inaequidens DC.) rapidly spread across Central Europe after its introduction, but we still do not know to what extent its timing of arrival in a plant community (i.e. before or after natives) and the composition of the native community being invaded affect (1) its capacity to invade a European grassland, (2) the performance of the native species, and (3) the direction and strength of priority effects. In a greenhouse experiment, we manipulated the timing of arrival of the exotic species (Senecio) and the composition of the native community to test the influence of these factors on the productivity and $\mathrm{N}$ content of exotic and native species. We also investigated if the plant species origin (native or exotic) and the native community composition affected the benefit of arriving early and the cost of arriving late in the community. The establishment success of Senecio strongly depended on its timing of arrival in a grassland community. Senecio benefited more from arriving early than did the natives. The presence of legumes in the community did not favour invasion by Senecio. When natives arrived later than Senecio, however, priority effects were weaker when legumes were part of the native community. Our results showed that inhibitory priority effects created by natives can lower the risk of invasion by Senecio. An early arrival of this species at a site with low native species abundance is a scenario that could favour invasion.
\end{abstract}

Keywords Grassland invasion · Native community composition · Order and timing of arrival $\cdot$ Priority effects $\cdot$ Restoration

\section{Introduction}

Invasion of plant communities by non-native ("exotic" or "alien") species is largely recognized as one of the main drivers of biodiversity loss worldwide (Sala et al. 2000;

Communicated by Brian J. Wilsey.

Electronic supplementary material The online version of this article (https://doi.org/10.1007/s00442-019-04521-x) contains supplementary material, which is available to authorized users.

Benjamin M. Delory

Benjamin.Delory@leuphana.de

Vicky M. Temperton

Vicky.Temperton@leuphana.de

Emanuela W. A. Weidlich

emanuela.ww@gmail.com

1 Ecosystem Functioning and Services, Institute of Ecology, Leuphana University, Universitätsallee 1, 21335 Lüneburg, Germany

2 Present Address: Botanical Department, Universidade Federal de Santa Catarina, Florianópolis, Brazil
Elbakidze et al. 2018). In Europe, the number of alien vascular plant species has increased steadily since the beginning of the nineteenth century, mainly because of enhanced economic activities such as trade and tourism increasing the risk of invasion (Elbakidze et al. 2018). Amongst all the exotic invasive plant species introduced to Europe, the South African ragwort (Senecio inaequidens DC., Asteraceae; hereafter referred to as Senecio throughout the article) is often considered as a fast spreading invader (Lachmuth et al. 2010) and this is probably linked to its ability to colonize a wide range of ecological habitats (Heger and Böhmer 2005). Senecio is a large perennial forb whose seeds have been repeatedly introduced to locations in Central Europe via the transport of sheep wool imported from the Eastern highlands of South Africa (Ernst 1998; Lachmuth et al. 2010). It was observed for the first time in Europe (West Germany) at the end of the nineteenth century (Ernst 1998; Heger and Böhmer 2005) and, after a time lag of nearly 80 years, it started to spread across Germany, mainly from a population introduced in Belgium at the beginning of the twentieth century (Lachmuth et al. 2010). It is an early-successional ruderal species requiring open sites with little resource competition and is 
mainly found on disturbed sites, including along railway tracks (Heger and Böhmer 2005).

The invasion success of an exotic species in a new environment is multifactorial (Seastedt and Pyšek 2011). Most of the research in this area has focused on two complementary aspects of plant invasion. A first area of research deals with the identification of traits favouring the invasiveness of exotic species, such as high competitive ability (Sakai et al. 2001; Perkins and Hatfield 2014), high propagule pressure and phenotypic plasticity (Kolar and Lodge 2001; Allendorf and Lundquist 2003; Wainwright and Cleland 2013), the ability to reproduce vegetatively/clonal growth (Kolar and Lodge 2001), or the ability to produce allelochemicals that suppress local species at new sites (Callaway and Aschehoug 2000; Callaway and Ridenour 2004; Aschehoug et al. 2014). A second area of research deals with the identification of native plant community characteristics affecting their susceptibility to invasion (invasibility), such as the disturbance regime (Chytrý et al. 2008; Seastedt and Pyšek 2011), resource availability (Davis et al. 2000; Zefferman et al. 2015; Liu et al. 2018), species and functional group richness (Tilman 1997; Knops et al. 1999; Naeem et al. 2000; Wardle 2001; Kennedy et al. 2002; Fargione and Tilman 2005; Pokorny et al. 2005; Scherber et al. 2010; Mason et al. 2017), species and functional group composition (Crawley et al. 1999; Prieur-Richard et al. 2002; Fargione et al. 2004; Wardle et al. 2011; Byun et al. 2013; Yannelli et al. 2017), and the presence of natural enemies (Keane and Crawley 2002; Shea and Chesson 2002; Levine et al. 2004). Because exotic species often germinate more quickly, grow faster, and take up resources more efficiently than native species (Wainwright et al. 2012; Wilsey et al. 2015), the invasion process is also tightly linked to the concept of priority effect in ecology, in which the species arriving first at a site significantly affect the development, growth, and reproduction of species arriving later (Chase 2003; Vannette and Fukami 2014; Temperton et al. 2016).

In grasslands, priority effects caused by biotic interactions can have effects that supersede abiotic influence on the community. Priority effects caused by species arriving before others can affect community structure as well as ecosystem functioning both aboveground (Wilsey et al. 2015; Weidlich et al. 2017) and belowground (Körner et al. 2008; Weidlich et al. 2018). Such priority effects occur either because the early-arriving species reduce the amount of resources (water, nutrients, space, etc.) available for late-arriving species (called niche pre-emption) (Fukami 2015), or because the early-arriving species modified the type of niches available for the species arriving later via, for instance, extra nitrogen $(\mathrm{N})$ availability if $\mathrm{N}_{2}$-fixing species arrive first, root exudation or the selection of a particular soil microbiome (called niche modification, including plant-soil feedbacks) (Callaway et al. 2004; Suding et al. 2013; van der Putten et al.
2013; Perkins and Hatfield 2014; Fukami 2015). Despite its importance for the restoration of sites threatened by exotic species invasion, we still know very little about how differences in timing of arrival between exotic and native species affect native-exotic relationships in European grasslands (but see Lang et al. 2017). Depending on how the development, growth, or reproduction of late-arriving species is affected by species that arrive early during assembly, priority effects can be either positive (i.e. late species favoured by early species) or negative (i.e. late species inhibited by early species). During ecological restoration of degraded landscapes, there is much potential for creating negative priority effects by sowing natives before the arrival of exotics (Hess et al. 2019). If exotic species with strong competitive abilities are given a head-start (e.g. after a disturbance), however, they can quickly outcompete or exclude the establishment of native species (Abraham et al. 2009; Grman and Suding 2010; Stevens and Fehmi 2011; Dickson et al. 2012; Wainwright et al. 2012; Ulrich and Perkins 2014; Wilsey et al. 2015; Stuble and Souza 2016), and such priority effects can persist for several years (Martin and Wilsey 2012; Vaughn and Young 2015).

To what extent the timing of arrival of Senecio (i.e. before or after natives) affects its capacity to invade a European grassland community is not yet known but, considering that (1) it is an early-colonizing species able to produce a large amount of wind-dispersed seeds (Ernst 1998), (2) it has the capacity to colonize and survive in mature grassland communities (Scherber et al. 2003), and (3) introduced Senecio populations respond to greater resource availability by increasing aboveground and belowground productivity and reproductive output (Bossdorf et al. 2008), it is likely that an early arrival of this species (i.e. before natives) could lead to successful invasion of grassland communities. In contrast, we expect that negative priority effects created by sowing natives before the arrival of the exotic species would lower the risk of invasion of grassland communities by Senecio.

Both direct and indirect facilitation between invading exotic species (Simberloff and Von Holle 1999; Flory and Bauer 2014) or between natives and exotics (Bruno et al. 2003; Bulleri et al. 2008; Saccone et al. 2010) are important invasion mechanisms. When looking at the effect of natives on exotics, facilitation in the form of $\mathrm{N}$ fertilization by leguminous species as well as nurse plant interactions have been shown to increase communities' susceptibility to invasion (Maron and Connors 1996; Mason et al. 2013). With regard to grassland ecosystems, the presence of legumes is known to increase the amount of $\mathrm{N}$ available for its neighbours via two co-occurring mechanisms: (1) direct $\mathrm{N}$ transfer ( $\mathrm{N}$ transfer) from legumes to non-legume neighbours, and (2) reduced interspecific competition for soil mineral $\mathrm{N}$ ( $\mathrm{N}$ sparing) when legumes derive most of their $\mathrm{N}$ from the atmosphere (Temperton et al. 2007). How such facilitation 
mechanisms affect the invasiveness of an exotic species has been the central issue in many research studies, with some showing that the presence of $\mathrm{N}_{2}$-fixing species in the community can favour invasion (Prieur-Richard et al. 2000, 2002; Mwangi et al. 2007; Scherber et al. 2010), and others not showing such positive relationship between invasibility and legume presence (Tilman 1997). In contrast, the presence of strong competitors, such as grasses, tends to increase the resistance of a plant community to invasion (Prieur-Richard et al. 2000, 2002; Fargione et al. 2004; Mwangi et al. 2007; Scherber et al. 2010). As described above, both the species and functional group composition of a native plant community can have important consequences for invasion but, surprisingly, little is known about the effect of this factor on the establishment of Senecio in European grasslands. Because $\mathrm{N}$ facilitation can be expected when legumes are present in a community, we hypothesize that grassland communities containing $\mathrm{N}_{2}$-fixing species would be more susceptible to invasion by Senecio than communities containing only grasses. In other words, we expect to find weaker priority effects of native species on Senecio if legumes are present in the community being invaded (i.e. Senecio benefits more than natives from the presence of legumes that arrived earlier than it did). Similarly, when the exotic species is the first to arrive in the community, we also expect to find weaker priority effects acting on the late-arriving native species if legumes are present (i.e. greater functional complementarity reducing interspecific competition).

In this paper, we present the results of a controlled greenhouse experiment designed to evaluate the benefits of arriving early and the costs of arriving late (i.e. priority effects) for the exotic species Senecio colonizing a community composed of species characteristic of mesotrophic temperate European grasslands. The costs and benefits for native species arriving earlier or later than Senecio were also evaluated in this study. In addition to time of arrival, we also manipulated the composition of the native community to test if this would affect the strength and direction of priority effects for both native and exotic species. Here, we addressed the following questions:

(1) How does the invasiveness of Senecio in a European grassland community depend on its timing of arrival and the composition of the native community?

(2) How is the performance of the native species affected by the timing of arrival of Senecio and the composition of the native community?

(3) Does Senecio benefit more than the native species from arriving early in the community?

(4) Does the composition of the native plant community affect the direction and strength of priority effects for exotic and native species?
(5) Do the native species pay a greater cost than Senecio when arriving late in the community?

\section{Materials and methods}

\section{Plant material}

All seeds used for the experiment described in this paper were native wild species, not cultivars, provided by RiegerHofmann GmbH (Blaufelden-Raboldshausen, Germany).

\section{Experimental design}

We set up an experiment using a full factorial and randomized design to test the influence of two main factors on the performance of an exotic (Senecio inaequidens) and native species characteristic of temperate mesotrophic European grasslands: (1) the timing of arrival of the exotic species in the plant community, and (2) the composition of the native plant community. With regard to the timing of arrival of the exotic species, it was sown either earlier, later, or at the same time (synchronous) as the native species. Because manipulating the timing of arrival of the exotic species implied the organization of two sowing events, two synchronous treatments were set up so that all priority effect treatments could be directly compared to plants that had grown for the same length of time: one at the first sowing (Synchronous 1 ), and another one at the second sowing (Synchronous 2). Therefore, the factor timing of arrival of the exotic species comprised a total of four levels (Fig. 1). Two different native plant communities were used in this experiment. In the first scenario, Senecio was sown into a community composed of grasses only (Holcus lanatus, Festuca pratensis, Phleum pratense). In the second scenario, it was sown into a community composed of grasses (H. lanatus, $F$. pratensis, $P$. pratense) and legumes (Medicago sativa, Trifolium pratense, Lotus corniculatus). Each of the 8 treatment combinations (4 timing of arrival of Senecio $\times 2$ native plant community compositions) was replicated 5 times. This experiment was set up in a greenhouse located in Rotes Feld, Lüneburg (Lower Saxony, Germany). During the period of the experiment, the temperature inside the greenhouse was $23.5 \pm 5.2{ }^{\circ} \mathrm{C}$ during the day and $16.8 \pm 2.8{ }^{\circ} \mathrm{C}$ during the night.

Eight days before the start of the experiment, $5 \mathrm{~L}$ of sand was added at the bottom of 40 pots (volume: 18.4 L, top surface area: $28 \times 28 \mathrm{~cm}^{2}$, height: $30 \mathrm{~cm}$ ). Then, the pots were filled with a mixture of sand $(50 \%, \mathrm{v} / \mathrm{v})$ and potting soil $(50 \%, \mathrm{v} / \mathrm{v})$ up to the top. After filling, the pots were placed inside a greenhouse and were watered twice before the start of the experiment. We started the experiment by sowing the species arriving first in the communities (Fig. 1). Depending on the timing of arrival of the 


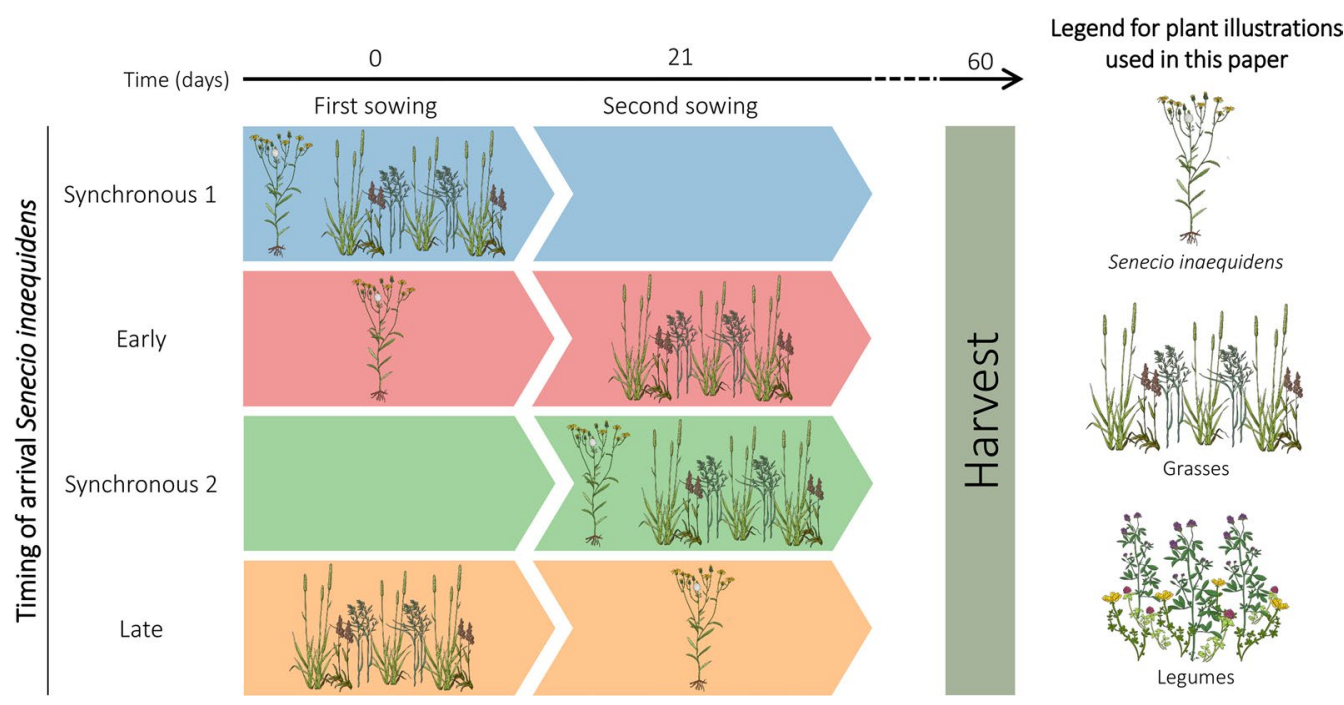

Fig. 1 Illustration of one scenario for manipulating arrival of Senecio relative to the native community that was tested in this study. A second scenario in which Senecio was sown a community composed of grasses and legumes was also tested (not shown). Note that, as shown in this figure and all subsequent figures, the terms "late" or

exotic species, we sowed either Senecio (Early arrival), the native species (Late arrival), or both Senecio and the native species (Synchronous 1). A grassland experiment that tested the influence of priority effects as well as sowing density and interval (comparing three and 6 weeks) on aboveground productivity found that although sowing interval played a role, the priority effect was much larger (von Gillhaussen et al. 2014). Based on this as well as many priority effect studies using a three-week sowing interval (Ulrich and Perkins 2014; Wilsey et al. 2015), we decided to sow the rest of the species in the pots of our experiment 21 days after the first sowing (Fig. 1). During this second sowing event, we sowed either the native species (Early arrival), Senecio (Late arrival), or both Senecio and the native species (Synchronous 2). After each sowing event, a thin layer of sand and potting soil $(50 \% / 50 \%, \mathrm{v} / \mathrm{v})$ was added at the top of the pots to favour germination. For each treatment, the sowing density of each species was adjusted to take into account differences in plant composition and germination rates so to allow for an even community outcome. When the native community was composed of grasses only, the sowing density was adjusted to reach a target of 50 individuals/species growing in the pots. When the native community was composed of a mixture of grasses and legumes, however, the sowing density was adjusted to reach a target of 25 individuals/species. For all treatments, the sowing density of the exotic species was calculated to reach a target of 25 individuals growing in each pot. The composition and sowing densities used for each plant community are summarized in Online Resource "early" always refer to the timing of arrival of the exotic species, not the background community. The colour code is the same as in Fig. 6. A legend for plant illustrations used throughout this paper is provided on the right side of the figure. Plant illustrations by Carolina Levicek. The colour version of the figure is available online

1. All pots were regularly watered using tap water throughout the duration of the experiment.

Sixty days after the first sowing event, the aboveground biomass was harvested separately for Senecio, the legumes, and the grasses. Plants were healthy and did not show obvious signs of pathogen or herbivore attack. Shoot samples were then dried at $70{ }^{\circ} \mathrm{C}$ until constant mass was reached.

Since all plant individuals used in this experiment were grown under the same experimental conditions, the differences in biomass production between Synchronous 1 and Synchronous 2 plants are mainly due to the difference in growth duration between the two treatments (i.e. Synchronous 1 plants grew for a total of 60 days, while Synchronous 2 plants grew for a total of 39 days). Temperature variations during the experiment are unlikely to explain the differences in biomass production observed between synchronous treatments, as the average day and night temperatures for the first 21 days (day: $24.9^{\circ} \mathrm{C}$; night: $18.6^{\circ} \mathrm{C}$ ) and the last 39 days of growth (day: $24.0^{\circ} \mathrm{C}$; night: $18.7^{\circ} \mathrm{C}$ ) were very similar.

\section{Measurements}

For each pot, we measured the total shoot dry weight of Senecio, legumes, and grasses. The total carbon (\%C) and nitrogen $(\% \mathrm{~N})$ content in Senecio, legume, and grass shoots (the latter were pooled into grass or legume biomass) was determined with a $\mathrm{C} / \mathrm{N}$ analyser (Vario EL; Elementar, Langenselbold, Germany) using $14.7 \pm 1.5 \mathrm{mg}$ of dry and finely ground material. Evidence for $\mathrm{N}$ facilitation in communities containing legumes was investigated using the $\delta^{15} \mathrm{~N}$ natural 
abundance method (sensu Temperton et al. 2007). Sample $\delta^{15} \mathrm{~N}$ values (\%o) were calculated using Eq. 1, where R represents the ratio of ${ }^{15} \mathrm{~N} /{ }^{14} \mathrm{~N}$ isotopes. $R_{\text {sample }}$ values were determined using an elemental analyser (Elementar Vario EL Cube) coupled to a stable isotope ratio mass spectrometer (IR-MS, Isoprime). Isotope ratios were determined for Senecio, grasses, and legumes using dried and finely ground plant material (Senecio: $7.6 \pm 1.1 \mathrm{mg}$; grasses: $6.7 \pm 0.1 \mathrm{mg}$; legumes: $9.0 \pm 0.1 \mathrm{mg}$ ). Atmospheric $\mathrm{N}_{2}$ is the international standard used for IR-MS measurements of $\delta^{15} \mathrm{~N}\left(R_{\text {standard }}\right)$. If legumes were actively fixing atmospheric $\mathrm{N}_{2}, R_{\text {sample }}$ values measured in their shoots should be very close to the $R_{\text {standard }}$ value measured in the atmosphere. Therefore, the expected $\delta^{15} \mathrm{~N}$ value measured in the shoots of actively fixing legumes should be close to zero. For species relying solely on soil N, however, we expect $\delta^{15} \mathrm{~N}$ values to be different from zero (in theory, close to the soil $\delta^{15} \mathrm{~N}$ value) because soil $\mathrm{N}$ often has a greater ${ }^{15} \mathrm{~N}$ abundance than atmospheric $\mathrm{N}_{2}$ (Unkovich et al. 2008). Apparent $\mathrm{N}$ transfer between legumes and non-legume neighbours was assessed by comparing the $\delta^{15} \mathrm{~N}$ values measured in Senecio and grass shoots growing with or without legumes in the community. If belowground $\mathrm{N}$ transfer occurred, we expect non-legume shoots to have lower $\delta^{15} \mathrm{~N}$ values when growing in communities containing leguminous species (Temperton et al. 2007). Because non $\mathrm{N}_{2}$-fixing species can also benefit from the soil $\mathrm{N}$ that is not taken up by leguminous species ( $\mathrm{N}$ sparing), we used both the $\mathrm{N}$ status $(\% \mathrm{~N})$ and the $\delta^{15} \mathrm{~N}$ values measured in plant shoots to investigate how $\mathrm{N}$ dynamics were affected by the timing of arrival of the exotic species and the species composition of the native community.

$\delta^{15} \mathrm{~N}=\left(\frac{R_{\text {sample }}}{R_{\text {standard }}}-1\right) \times 1000$.

\section{Quantification of priority effects}

In assembly research, the strength of priority effects has mainly been quantified using interaction indices in the form of log response ratios (Vannette and Fukami 2014; Stuble and Souza 2016). Because such indices are not bounded between finite values, they are however not well suited for comparing results between different experiments (DíazSierra et al. 2017). Here, we introduce a set of standardized, symmetric, and bounded interaction indices designed to quantify the benefit of arriving early $(B)$ and the cost of arriving late $(P)$ during community assembly (Table 1 ; note that in our definition of priority effects, these only occur as effects on later arriving species). These indices share the same mathematical properties as the relative interaction index commonly used to measure competition and facilitation between interacting plants, i.e. they are standardized, symmetric around zero, and are bounded between -1 and +1 (Díaz-Sierra et al. 2017). To the best of our knowledge, this study is the first to use a set of interaction indices derived from the well-known relative interaction index to quantify the benefit of arriving early and the cost of arriving late during assembly. The direction of the priority effect is given by the sign of $P$, with inhibitory priority effects having negative values, and facilitative priority effects having positive values. The strength of the priority effect is given by the absolute value of $P$. Because the calculation of $B$ and $P$ relies on the comparison of the performance of organisms arriving at different time in the community, but having the same age at harvest (e.g. Senecio growing in Early and Synchronous 1 treatments; see Fig. 1), they can only be calculated if the experiment includes as many synchronous treatments (i.e. all species arriving at the same time) as sowing events. The values for $P$ and $B$ reported in this paper were all calculated using shoot dry weight data. The total biomass of native species in the community was calculated by summing the biomass of legumes and grasses. In the supplementary material, cost and benefit values calculated using shoot $\mathrm{N}$ content data are also provided (Online Resource 5).

\section{Statistical analyses}

Generalised linear models (GLMs) were used to investigate the effect of the timing of arrival of the exotic species (Arrival), the species composition of the native plant community

Table 1 Quantifying the benefit of arriving early and the cost of arriving late during assembly. In the equations, $Y$ is a particular response variable (e.g. biomass production, $\mathrm{N}$ content, etc.)

\begin{tabular}{|c|c|c|c|c|c|}
\hline & \multirow[t]{2}{*}{ For the exotic species } & \multirow[t]{2}{*}{ For the native species } & \multicolumn{3}{|l|}{ Interpretation } \\
\hline & & & Negative values & 0 & Positive values \\
\hline $\begin{array}{l}\text { Benefit (B) of arriving } \\
\text { early }\end{array}$ & $B_{E}=\frac{Y_{E}^{E a r l y}-Y_{E}^{\text {Sync1 }}}{Y_{E}^{\text {Early }}+Y_{E}^{\text {Sycl }}}$ & $B_{N}=\frac{Y_{N}^{\text {Late }}-Y_{N}^{\text {Sync } 1}}{Y_{N}^{\text {Late }}+Y_{N}^{\text {Sync1 }}}$ & $\begin{array}{l}\text { Negative effect of early } \\
\text { arrival }\end{array}$ & No benefit & $\begin{array}{l}\text { Positive effect of early } \\
\text { arrival }\end{array}$ \\
\hline Cost $(\mathrm{P})$ of arriving late & $P_{E}=\frac{Y_{E}^{\text {Late }}-Y_{E}^{\text {Sync } 2}}{Y_{E}^{\text {Late }}+Y_{E}^{\text {Syyc2 }}}$ & $P_{N}=\frac{Y_{N}^{\text {Early }}-Y_{N}^{\text {Sync } 2}}{Y_{N}^{\text {Early }}+Y_{N}^{\text {Sync2 } 2}}$ & $\begin{array}{l}\text { Negative (or inhibitory) } \\
\text { priority effect }\end{array}$ & No priority effect & $\begin{array}{l}\text { Positive (or facilitative) } \\
\text { priority effect }\end{array}$ \\
\hline
\end{tabular}

The superscripts and subscripts refer to the timing of arrival of the exotic species (as shown in Fig. 1) and the origin of the plant species on which $Y$ was measured ( $E$ is for exotic, $N$ is for natives), respectively 
(Composition), and their interaction (Interaction) on the aboveground biomass productivity of the exotic species and the grasses. Because the number of Senecio individuals that established varied from pots to pots, we tested if adding the number of Senecio individuals that were actually growing in the pots as a covariate would improve the quality of the models. After comparing models fitted with and without the number of Senecio individuals, we did not find any evidence to support that models accounting for the number of Senecio individuals were better than the models that did not account for it. In addition, there was no correlation between the number of Senecio individuals growing in a pot and the total productivity achieved by the exotic species $(r=0.15, P=0.35)$. Therefore, in this paper, we only report the results of statistical models fitted without using the number of Senecio individuals growing in the pots as a covariate. When the interaction term did not significantly improve the model, a new model without interaction term was fitted. GLMs were also used to investigate the effect of the timing of arrival of the exotic species on the aboveground productivity of the legumes. GLMs were always fitted on plant biomass data using a Gamma distribution and a log-link function.

The effect of the timing of arrival of the exotic species, the species composition of the native plant community, and their interaction on the $\mathrm{C} / \mathrm{N}$ content and $\delta^{15} \mathrm{~N}$ values measured in Senecio and grass shoots was investigated using two-way ANOVA models. One-way ANOVA models were used to test for the effect of the timing of arrival of the exotic species on the $\mathrm{C} / \mathrm{N}$ content and $\delta^{15} \mathrm{~N}$ values measured in legume shoots.

Two-way ANOVA models were used to test if the plant species origin (native or exotic), the native community composition, and their interaction had an effect on the benefit of arriving early $\left(B_{E}\right.$ or $\left.B_{N}\right)$ and the cost of arriving late $\left(P_{E}\right.$ or $\left.P_{N}\right)$ in the community. When reported, $95 \%$ confidence intervals were computed by bootstrapping (1000 iterations) using the percentile method. We considered that the mean value of a group was not significantly different from zero when the $95 \%$ confidence interval of that group included zero.

General linear hypotheses (post hoc tests) were tested using Tukey contrasts and the glht function of the multcomp R package (Hothorn et al. 2008). When results of post hoc tests are shown, adjusted $\mathrm{P}$ values (single-step method) are reported to account for multiple comparisons of group means. All statistical analyses were performed in R 3.4.3 (R Core Team 2018) with an alpha value of 0.05 .

\section{Results}

\section{Timing of arrival and native plant community composition affect the performance of Senecio}

When Senecio was the first species sown in a community, it produced significantly more biomass than when sown at the same time as the native species (Fig. 2a). The effect of the timing of arrival of Senecio on plant productivity, however, varied with the species composition of the native community (Interaction: $F_{1,16}=5.31$, $P=0.03$ ). If the native plant community contained both grasses and legumes, the biomass gain due to an early sowing of Senecio $(+138 \%)$ was larger than when the native community contained only grasses $(+64 \%)$. This result can be explained by the fact that, when both exotic and native species were sown at the same time, Senecio was less productive in communities containing legumes than in communities containing only grasses (Fig. $2 \mathrm{a} ; z=2.96$, $P=0.01$ ), while the biomass achieved by Senecio did not differ between both communities when it was sown earlier than the native species (Fig. 2a; $z=-0.15, P=1.0$ ). Whatever the composition of the native plant community, an early arrival of Senecio did not affect its N content (Fig. 2c; Arrival: $F_{1,16}=1.19, P=0.29$; Composition: $F_{1,16}=0.37, P=0.55$; Interaction: $F_{1,16}=4.33, P=0.05$ ). With regard to the C content of Senecio shoots, it was negatively affected by an early arrival of Senecio (-3.8\%; Arrival: $F_{1,16}=9.29, P=0.01$; Composition: $F_{1,16}=1.13$, $P=0.30$; Interaction: $F_{1,16}=1.88, P=0.19$ ), particularly when the native community was composed of legumes and grasses (Online Resource 2a).

When the exotic species was sown later than the natives, it barely managed to establish and produced between $96 \%$ and $99 \%$ less biomass than the plants that were sown at the same time as the native species (Fig. 2b; Arrival: $\left.F_{1,16}=62.74, P<0.001\right)$. When sown later than the natives, the biomass achieved by Senecio did not depend on the composition of the native community (Composition: $F_{1,16}=1.16, P=0.30$; Interaction: $F_{1,16}=3.19, P=0.09$ ). For both plant community compositions, a late arrival of Senecio had a strong negative effect on its shoot N content (Fig. 2 d; arrival: $F_{1,15}=24.90, P<0.001$ ). Although we did not find any significant effect of the species composition of the native plant community on the $\mathrm{N}$ content of Senecio (Fig. 2d; Composition: $F_{1,15}=0.83, P=0.38$; Interaction: $F_{1,15}=1.53, P=0.23$ ), the decrease in $\mathrm{N}$ content associated with a late arrival of the exotic species was lower in communities containing legumes $(-24 \%)$ than in communities containing only grasses $(-39 \%)$. For both native community compositions, the C content of Senecio shoots was similar whether it was sown later or at the 
Fig. 2 Senecio's shoot dry weight and shoot $\mathrm{N}$ content under $\mathbf{a}, \mathbf{c}$ early and $\mathbf{b}, \mathbf{d}$ late timing of Senecio arrival in two native communities differing in species composition. All panels show the overall mean (horizontal dotted line), the mean of each group (long black horizontal lines, $n=4-5$ ), and each individual observation (short grey horizontal lines). Note that the terms "late" or "early" in all graphs always refer to the timing of arrival of the exotic species (Fig. 1). Because of the low shoot dry weight of Senecio obtained for one replicate of the treatment where the exotic species arrived late in a community made of native grass species only, we were not able to measure the $\mathrm{N}$ content of that replicate, leaving $n=4$ in this case. ns, not significant $(P>0.05)$; $* P<0.05$; $* * P<0.01 ; * * * P<0.001$
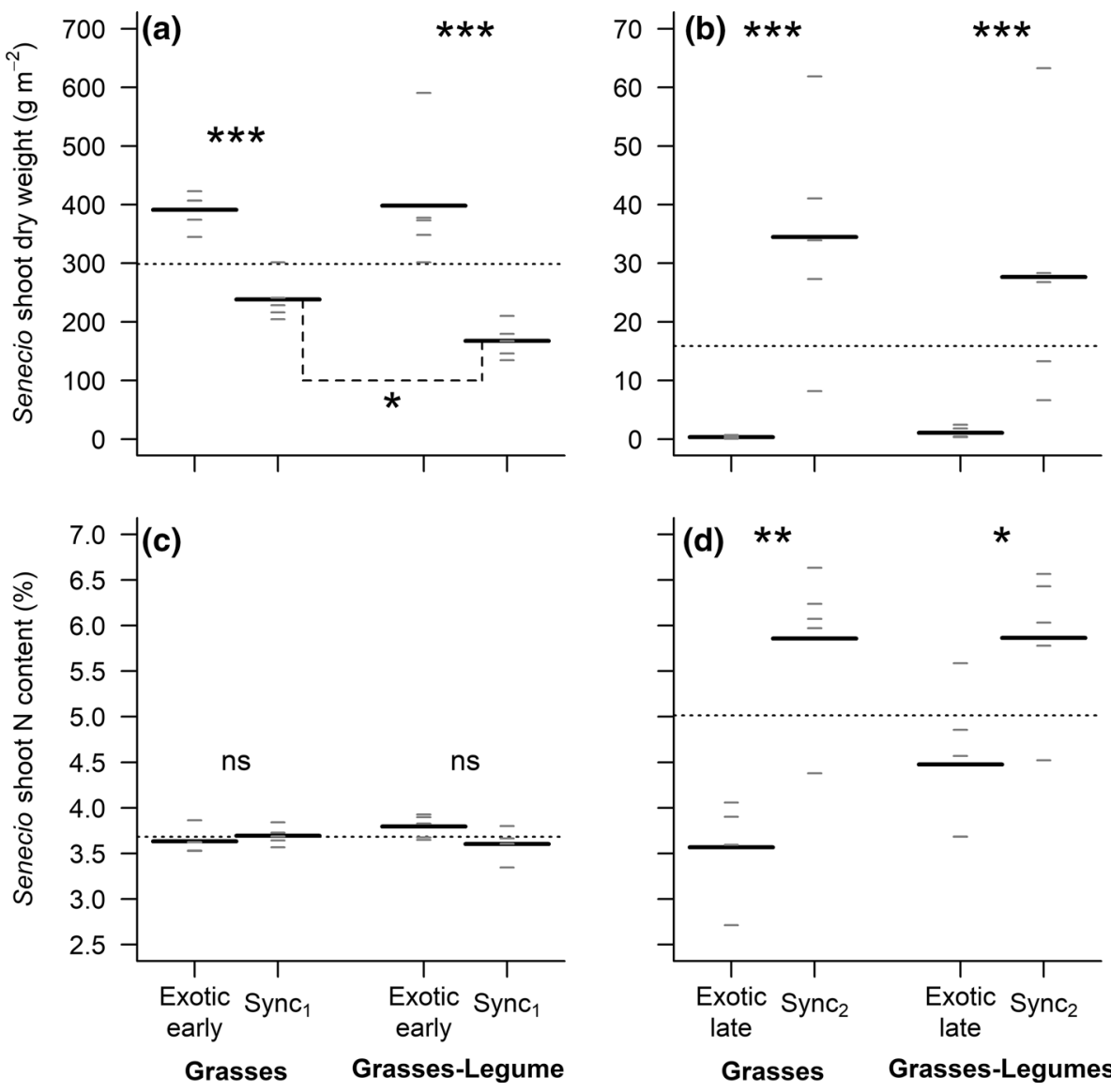

same time as the native species and did not differ between the two plant communities (Online Resource 2b; Arrival: $F_{1,15}=10^{-4}, P=1.0$; Composition: $F_{1,15}=0.94, P=0.35$; Interaction: $\left.F_{1,15}=1.74, P=0.21\right)$.

\section{Timing of arrival of the exotic species and plant community composition affect the biomass production and $\mathbf{N}$ content of native grass species}

In comparison with a situation where both native and exotic species were sown at the same time, the aboveground biomass of the grass species was between $62 \%$ and $66 \%$ greater if they were sown earlier than the exotic (Fig. 3a; Arrival: $\left.F_{1,16}=41.61, P<0.001\right)$, and this result was independent of plant community composition (Interaction: $F_{1,16}=0.02$, $P=0.88$ ). When the natives were sown before the exotic species, the timing of arrival of the exotic species was the only factor affecting the shoot $\mathrm{N}$ content (Fig. 3c; Arrival: $F_{1,16}=5.12, P=0.04$; Composition: $F_{1,16}=1.27, P=0.28$; Interaction: $\left.F_{1,16}=0.48, P=0.50\right)$. On average, the grasses had a lower $\mathrm{N}$ content when they were sown earlier than the exotic species. This difference in $\mathrm{N}$ content was no longer significant when the effect of the timing of arrival of the exotic species was investigated separately for each plant community (Fig. 3c).
Overall, the grasses established poorly when they were sown later than the exotic species. In this situation, they produced between $77 \%$ and $93 \%$ less biomass than the grasses that were sown at the same time as Senecio (Fig. 3b). This timing of arrival effect, however, was dependent on the native community composition (Interaction: $\left.F_{1,16}=4.84, P=0.04\right)$, mainly because the lower grass density in communities containing legumes led to a lower grass biomass production in these communities when all species arrived at the same time (Fig. 3b). On average, the grasses sown later than Senecio also had a significantly lower $\mathrm{N}$ content $(-24 \%)$ than the grasses that were sown at the same time as the exotic species, particularly when native communities did not contain any legumes (Fig. 3d; Arrival: $F_{1,16}=30.18, P<0.001$; Composition: $F_{1,16}=4.96, P=0.04$; Interaction: $F_{1,16}=4.31$, $P=0.05)$. For both native community compositions, the $\mathrm{N}$ content of grass shoots was lower when the native species were sown after the exotic, but the difference with the synchronous treatment was only significant when legumes were absent (Fig. 3d; $t=5.35, P<0.001$ ). In addition, when Senecio was the first species to arrive, the N content in grass shoots was $29 \%$ greater if the native community included legumes (Fig. 3d; $t=-3.04, P=0.03$ ). 
Fig. 3 Grasses' shoot dry weight and shoot $\mathrm{N}$ content under $\mathbf{a}, \mathbf{c}$ late and $\mathbf{b}, \mathbf{d}$ early timing of Senecio arrival in two native communities differing in species composition. All panels show the overall mean (horizontal dotted line), the mean of each group (long black horizontal lines, $n=5$ ), and each individual observation (short grey horizontal lines). Note that the terms "late" or "early" in all graphs always refer to the timing of arrival of the exotic species, such that the "late" treatment outcome shows the performance of grasses when they arrive early (Fig. 1). ns, not significant $(P>0.05)$; $* P<0.05$; $* * P<0.01 ; * * * P<0.001$
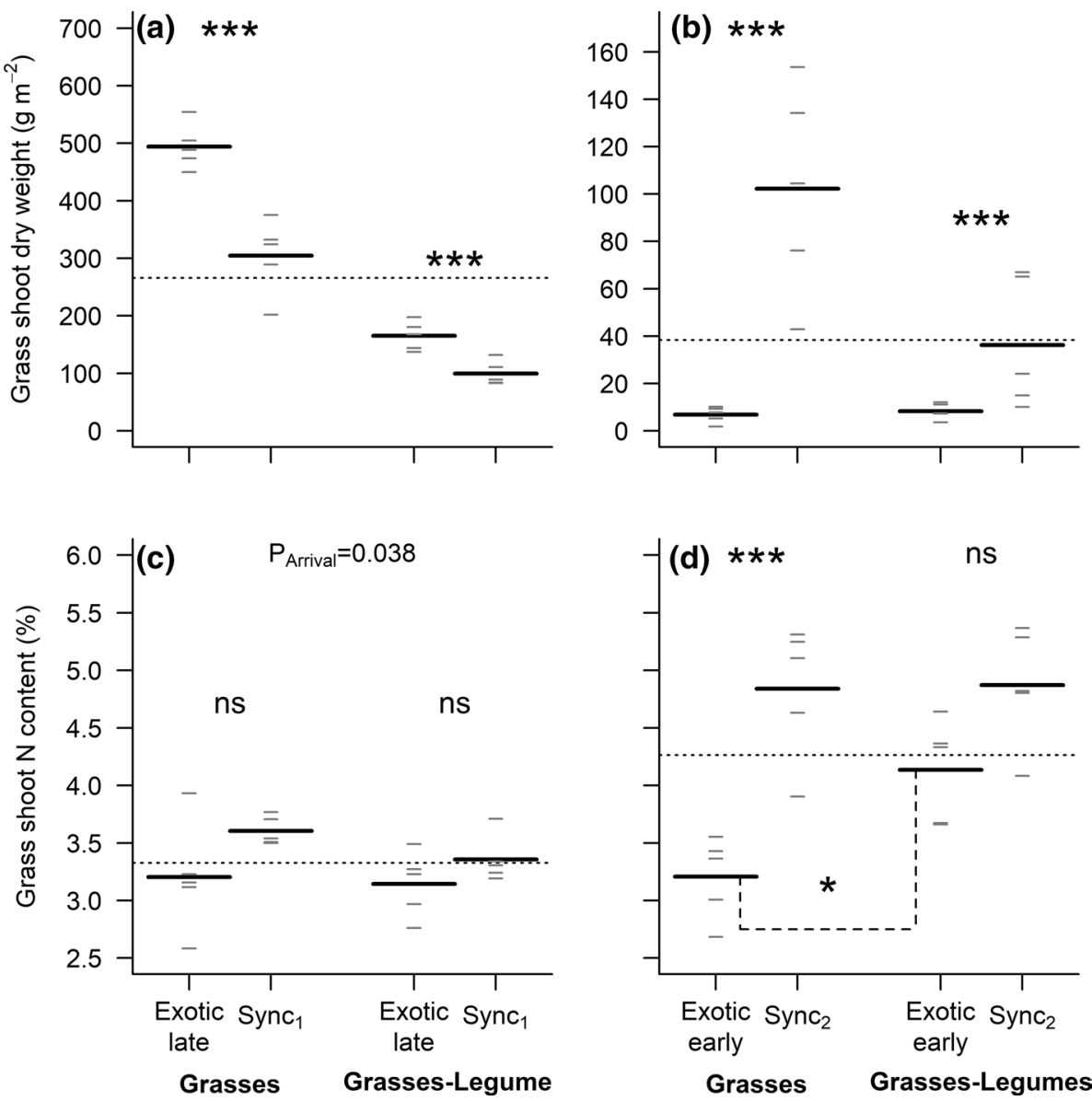

Neither timing of arrival of the exotic species nor the species composition of the native community affected the C content of grass tissues (Online Resource 3).

\section{Timing of arrival of the exotic species affects the biomass production and $\mathrm{N}$ content of native legume species}

When legumes were sown before Senecio, they were 44\% more productive than when sown at the same time as the exotic species (Fig. $4 \mathrm{a} ; F_{1,8}=27.87, P<0.001$ ). We did not observe any effect of a late arrival of the exotic species on the $\mathrm{N}$ content (Fig. $4 \mathrm{c} ; F_{1,8}=0.03, P=0.87$ ) and C content (Online Resource 4a; $F_{1,8}=0.88, P=0.38$ ) of legume shoots.

When Senecio was the first species to be sown in the community, the aboveground biomass and the shoot $\mathrm{N}$ content of the legumes decreased by $61 \%$ (Fig. $4 \mathrm{~b} ; F_{1,8}=25.54$, $P<0.001$ ) and $27 \%$ (Fig. 4 d; $F_{1,8}=66.36, P<0.001$ ) in comparison with control plants sown at the same time as the exotic species, respectively. An early arrival of the exotic species did not have an effect on the $\mathrm{C}$ content of legume tissues (Online Resource 4b; $F_{1,8}=0.01, P=0.91$ ).

\section{Senecio benefits more from arriving early than the natives}

Our results showed that both exotic and native species benefited from arriving early in the community but, on average, Senecio benefited more than the natives (Fig. 5a; Species: $\left.F_{1,16}=5.56, P=0.03\right)$. Interestingly, the effect of the native community composition on the benefit of arriving early differed between exotic and native species (Fig. 5a; Interaction: $F_{1,16}=5.31, P=0.03$ ). The positive effect associated with an early arrival was greater for the exotic species if it was followed by a mixture of grasses and legumes compared with a mixture of grass species only $(t=2.56, P=0.04)$. For the natives, however, the benefit of arriving early was similar for both community compositions $(t=-0.70, P=0.74)$. Very similar results were obtained when the benefit of arriving early was calculated using shoot $\mathrm{N}$ content data (Online Resource 5).

\section{Arriving late is less costly for natives than Senecio, particularly when legumes are present in the community}

Both exotic and native species created inhibitory priority effects for species arriving later (Fig. 5b). Overall, growth 

weight and shoot $\mathrm{N}$ content under $\mathbf{a}, \mathbf{c}$ late and $\mathbf{b}, \mathbf{d}$ early panels show the overall mean (horizontal dotted line), the mean of each group (long black horizontal lines, $n=5$ ), and each individual observation (short grey horizontal lines). Note that the terms "late" or "early" in all graphs always refer to the timing of arrival of the exotic species, such that the "late" treatment outcome shows the performance of legumes when they arrive early (Fig. 1). ns, not significant $(P>0.05) ; * P<0.05$; $* * P<0.01 ; * * * P<0.001$
Fig. 4 Legumes' shoot dry timing of Senecio arrival. All
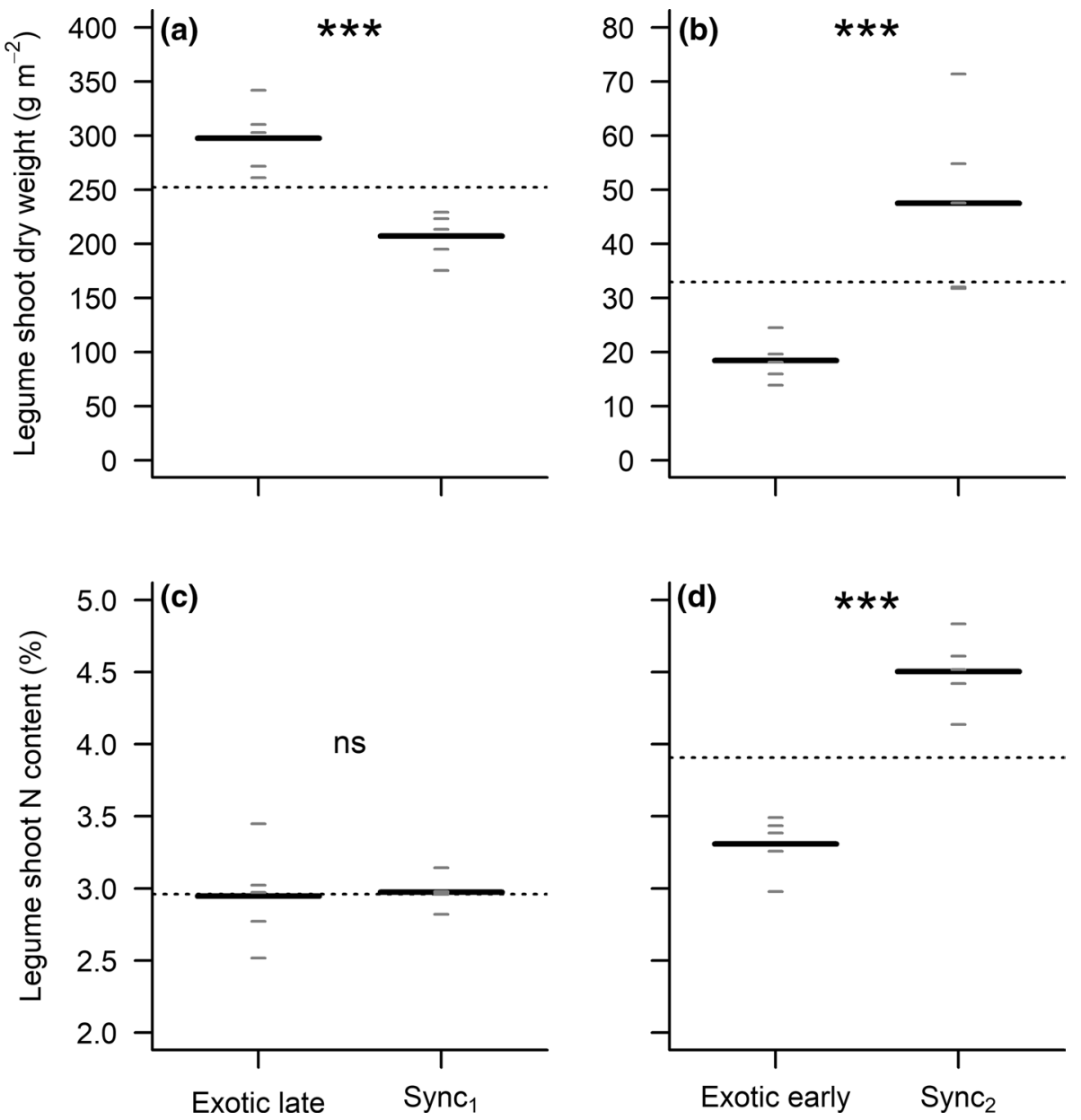

reduction by priority effects was strongest for the exotic species (Species: $F_{1,16}=19.45, P<0.001$ ) and when legumes were absent from the plant community (Community: $F_{1,16}=13.97, P=0.002$ ). In addition, the composition of the native community affected differently the priority effect strength measured on exotic and native species arriving later (Interaction: $F_{1,16}=6.63, P=0.02$ ). Our results showed that the strength of priority effects acting on Senecio did not depend on the composition of the native community it tried to invade $(t=0.82, P=0.66)$. The strength of priority effects acting on native species, however, was significantly affected by the composition of the native community. In comparison with a scenario where the native community is composed of grasses only, inhibitory priority effects acting on natives following an early establishment of the exotic species were on average $46 \%$ weaker when legumes were present in the native community ( $t=4.46, P<0.001)$. Very similar results were obtained when the strength of priority effects was calculated using shoot $\mathrm{N}$ content data (Online Resource 5).

\section{Evidence for atmospheric $\mathrm{N}_{2}$ fixation by legumes, but not for $\mathbf{N}$ transfer to non-legume neighbours}

On average, the $\delta^{15} \mathrm{~N}$ values measured in legume shoots were $48 \%$ and $42 \%$ lower than those measured in Senecio and grass shoots, respectively (Fig. 6a). This result strongly suggests that the legumes harvested at the end of the experiment were actively fixing atmospheric $\mathrm{N}_{2}$. However, the positive $\delta^{15} \mathrm{~N}$ values measured in legume shoots also indicate that the legumes did not rely solely on the fixation of atmospheric $\mathrm{N}_{2}$ as a source of $\mathrm{N}$ for plant growth, but also on the soil $\mathrm{N}$ pool.

The $\delta^{15} \mathrm{~N}$ values measured in the exotic species were affected by its timing of arrival (Arrival: $F_{2,24}=11.54$, $P<0.001)$ and by the composition of the native community being invaded (Composition: $F_{1,24}=6.19, P=0.02$ ), but not by the interaction between these two factors (Interaction: $F_{2,24}=2.11, P=0.14$ ) (Fig. 6b). Surprisingly, Senecio shoots had greater $\delta^{15} \mathrm{~N}$ values when legumes were present in the community $(t=3.10, P=0.005)$. In addition, Senecio shoots from the Synchronous 2 treatment 

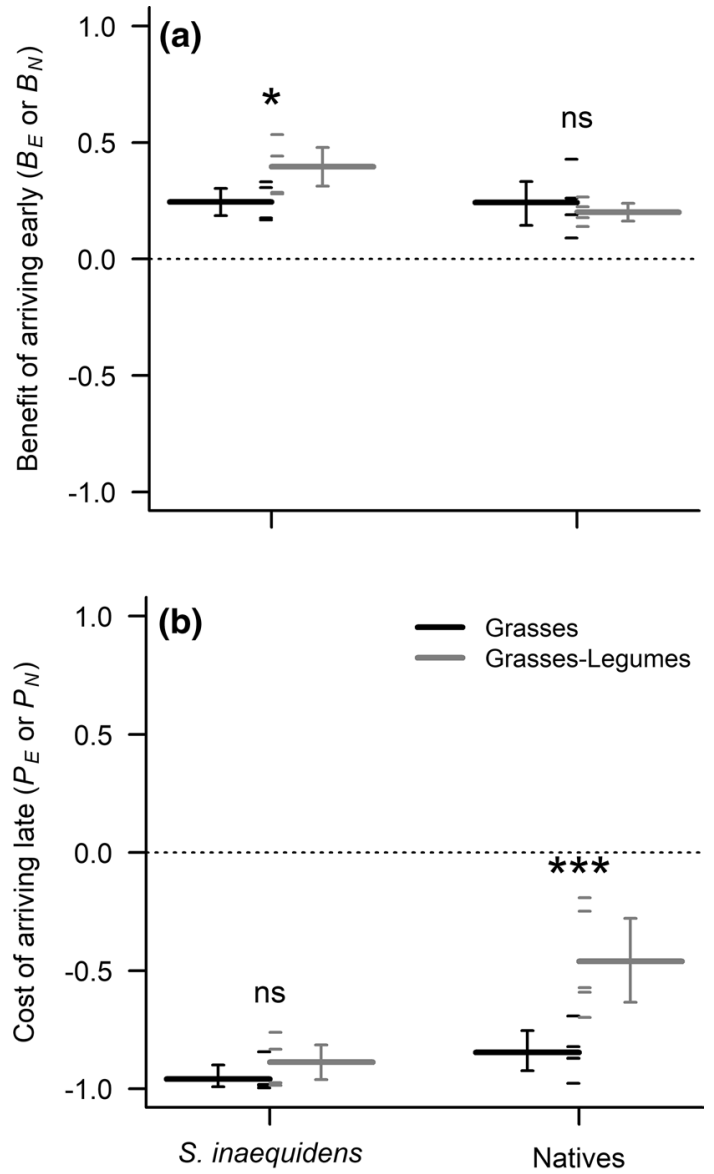

Plant species origin

Fig. 5 a Benefit of arriving early and $\mathbf{b}$ cost of arriving late in the community for exotic and native species. Benefits and costs were calculated based on shoot dry weight data using the equations listed in Table 1. All panels show the mean of each group (long horizontal lines, $n=5$ ), and each individual observation (short horizontal lines). Results are shown separately for each plant species origin (exotic or natives) and each native community composition. Error bars are $95 \%$ confidence intervals computed by bootstrapping using the percentile method. If a 95\% confidence interval does not include zero, the mean value of the group is significantly different from zero. ns, not significant $(P>0.05) ; * P<0.05 ; * * P<0.01 ; * * * P<0.001$

also had greater $\delta^{15} \mathrm{~N}$ values than the ones harvested from the Early $(t=3.94, P=0.002)$ and Synchronous 1 treatments $(t=3.41, P=0.006)$.

When looking at the native species, the $\delta^{15} \mathrm{~N}$ values measured in grass shoots were affected neither by the timing of arrival of the exotic species (Arrival: $\mathrm{F}_{3,32}=1.59$, $P=0.21$ ) nor by the species composition of the native plant community (Composition: $\mathrm{F}_{1,32}=1.17, P=0.29$; Interaction: $\mathrm{F}_{3,32}=0.11, P=0.95$ ) (Fig. 6c). Similarly, there was only weak support that the timing of arrival of the exotic species affected the $\delta^{15} \mathrm{~N}$ values of legume shoots (Arrival: $\mathrm{F}_{3,16}=2.86, P=0.07$ ) (Fig. $6 \mathrm{~d}$ ).
Despite that legumes were actively fixing atmospheric $\mathrm{N}_{2}$ during our experiment, the fact that the shoot $\delta^{15} \mathrm{~N}$ values measured in Senecio and native grass species were not lower when grown in communities containing legumes did not support direct $\mathrm{N}$ transfer from legume to non-legume neighbours.

\section{Discussion}

The results presented here confirmed that the timing of arrival of Senecio has a strong impact on its performance. This exotic species performed much better (greater biomass production) when it was the first species to arrive in the community. In fact, pots in which the exotic species was sown before the natives were near monocultures, with Senecio accounting for $96 \%$ of the total aboveground biomass, while it accounted for only $40 \%$ of the total biomass when it was sown at the same time as the native species. On the other hand, it barely managed to establish (less than $0.6 \%$ of the total aboveground biomass) and had a lower $\mathrm{N}$ content when it arrived later. The timing of arrival of the exotic species in the community also strongly affected the performance of the native species. When the natives arrived 3 weeks before Senecio, they produced more biomass than natives arriving at the same time as the exotic species. When the natives arrived later in the community, however, they established poorly (lower biomass) and had a lower shoot $\mathrm{N}$ content. Therefore, whatever the origin of the plant species arriving first (either exotic or native), it created strong inhibitory priority effects for the species arriving later in the assembly process. These results are in line with previous studies that have shown that priority effects with either positive (lower abundance of exotic species) or negative (natives outcompeted by exotics) conservation outcomes can be created depending on whether the exotic species arrive later or earlier than the natives, respectively (Abraham et al. 2009; Grman and Suding 2010; Stevens and Fehmi 2011; Dickson et al. 2012; Wainwright et al. 2012; Ulrich and Perkins 2014; Wilsey et al. 2015; Stuble and Souza 2016).

Using nectar-inhabiting microorganisms as a model system, Vannette \& Fukami (2014) demonstrated that the priority effects are stronger if (1) species arriving at different time in the community use resources in a similar way (niche overlap), (2) early-arriving species have a strong impact on the local environment (impact niche), and (3) the growth, survival, and reproduction of late-arriving species is greatly affected by environmental conditions (requirement niche). Because both exotic and native species created strong inhibitory priority effects in our experiment, it is likely that the species that were sown first impacted the environment in such a way that it degraded the requirement component of the late-arriving species' niches. In an attempt to classify 


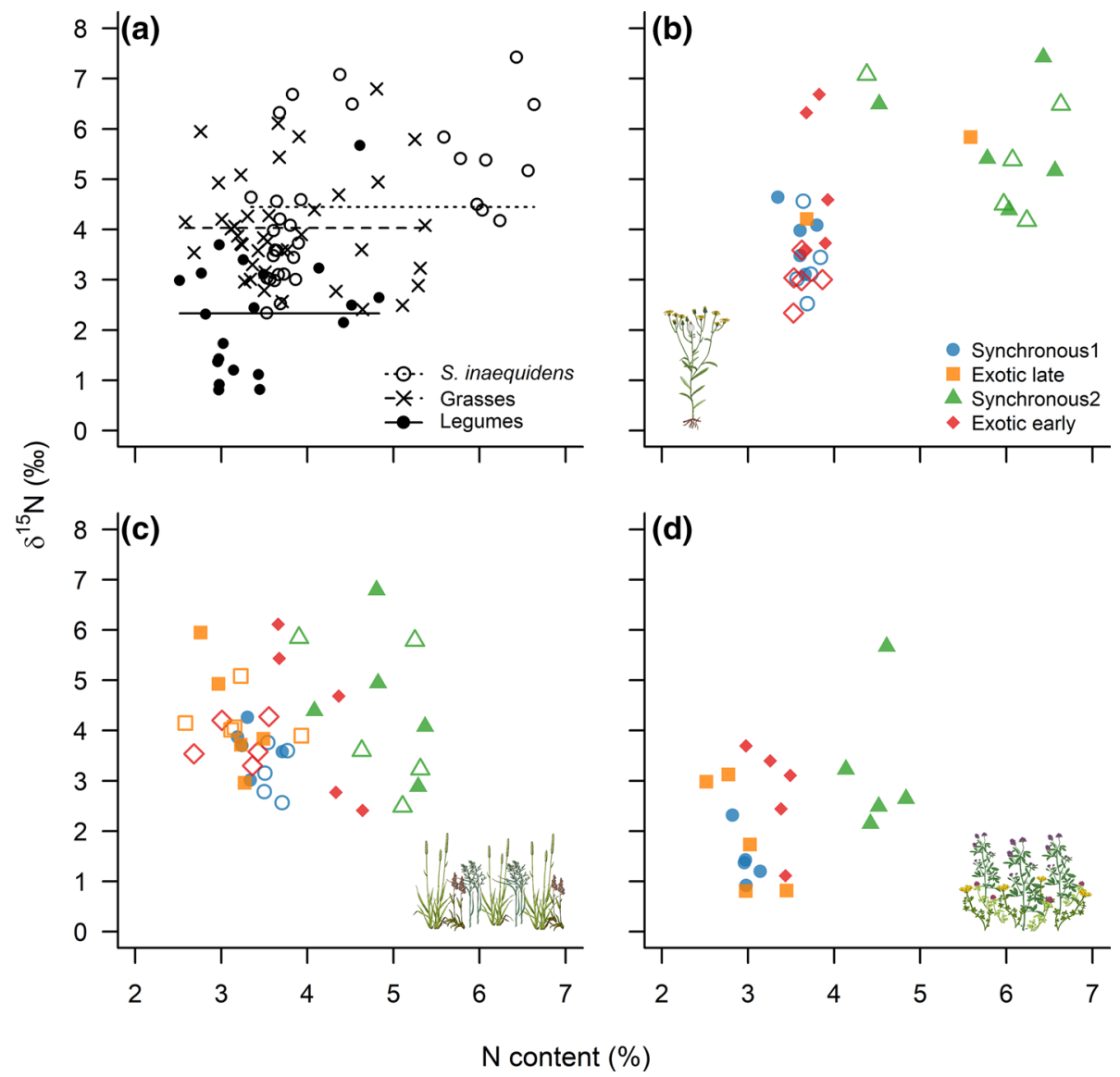

Fig. 6 Relationship between the $\mathrm{N}$ content and the $\delta^{15} \mathrm{~N}$ values measured in a, b Senecio, a, c grass, and a, $\mathbf{d}$ legume shoots. a Shows all data together. The horizontal lines represent the mean $\delta^{15} \mathrm{~N}$ values calculated for Senecio, the grasses, and the legumes (see legend a). b-d Dots are coloured based on the timing of arrival of the exotic species (see key in b). Open symbols refer to native communities containing only grasses, while closed symbols refer to native communities containing grasses and legumes. Because of the low shoot dry weight of Senecio obtained for one replicate of the treatment where

the mechanisms behind the creation of priority effects during community assembly, Fukami (2015) distinguished two main categories of mechanisms by which early-arriving species impact their local environment and affect the establishment of species arriving later. The first mechanism, referred to as niche pre-emption, is mainly resource driven. It is based on the assumption that the plant species arriving first at a site affects species arriving later by reducing the amount of available resources such as light, water, soil nutrients, and physical space itself. The second mechanism, referred to as niche modification, is based on the assumption that the species arriving first in the community will modify the types of niches available locally and will affect the identity of the species that will be able to colonize the community. Contrary to niche pre-emption mechanisms, which can only lead to the creation of inhibitory priority effects, niche the exotic species arrived late in a community made of native grass species only, we were not able to measure the $\mathrm{N}$ content of that replicate, giving $n=4$ for this treatment. For the same reason, we were not able to measure the $\delta^{15} \mathrm{~N}$ values in all replicates of the treatment where Senecio arrived late in a community composed of grass species only, as well as in three replicates of the treatment where Senecio arrived late in a community composed of grasses and legumes. The colour version of the figure is available online

modification mechanisms can lead to the creation of both facilitative (e.g. soil fertilization by leguminous species) or inhibitory priority effects (e.g. exudation of allelochemicals altering the growth rate of species arriving later) (Maron and Connors 1996; Callaway and Aschehoug 2000; Fukami 2015). Which class of mechanisms led to the creation of priority effects in our experiment is not clear yet, but the near competitive exclusion and lower $\mathrm{N}$ content of species arriving late in the community strongly suggest that niche pre-emption mechanisms played an important role (Fukami 2015). In addition, we did not find any evidence of apparent $\mathrm{N}$ transfer from legumes to non-legume neighbours in our experiment, thus not supporting niche modification by leguminous species via $\mathrm{N}$ fertilization.

Senecio being an early-successional species (Ernst 1998; Heger and Böhmer 2005), it is likely to be one of the first 
species to arrive at open sites, particularly in disturbed and stony areas. Our results showed that Senecio benefited more from arriving early in the community than the native species, and this effect was particularly strong when the following mixture included legumes. This result is in agreement with the hypothesis that, due to their earlier emergence, greater germination rates, and faster growth, exotics would benefit more than native species from arriving early in the community (Dickson et al. 2012; Wainwright et al. 2012; Wilsey et al. 2015; Hess et al. 2019). This result, however, contradicts other priority effect studies that showed that exotic species benefited equally (Stuble and Souza 2016) or less (Cleland et al. 2015) than natives when they were the first to arrive in a community. As suggested by Stuble \& Souza (2016), differences between studies could arise from differences between species and study systems (e.g. testing annuals vs perennials).

Overall, Senecio suffered more from arriving late than the native species. This key result contradicts previous studies that showed that the cost of arriving late in a plant community tends to be lower for exotics than for natives (Stuble and Souza 2016), or that exotics create stronger priority effects than natives (Wilsey et al. 2015). Arriving late was less costly for the native species than for the exotic species, suggesting a possible evolutionary adaptation of native grassland species to finding free niches despite high canopy cover of the community into which they are trying to establish. Interestingly, our results also showed that the strength of the priority effects acting on the exotic species did not depend on the composition of the native community being invaded. Contrary to our expectations, the growth inhibition of Senecio when it arrived in a community composed of native grasses only was as strong as when it arrived in a mixture of grasses and legumes. Because (1) the native grass community had a greater $\mathrm{N}$ content per unit plant biomass than the community composed of a mixture of grasses and legumes (Online Resource 6), and (2) the two native communities did not differ in productivity across our priority effect treatments (Online Resource 7), the grass community seemed better at taking up soil $\mathrm{N}$ than the grass-legume mixture in our experiment.

Even though the amount of soil $\mathrm{N}$ available for plant growth was probably greater in the community containing legumes, the fact that the strength of the priority effects acting on Senecio was not different between the two native communities used in our experiment strongly suggests that available soil $\mathrm{N}$ was not the limiting factor for the establishment of the exotic species in our artificial grassland communities. Instead, pre-emption of light or other soil resources by natives might be more important mechanisms to explain the near competitive exclusion of latearriving Senecio invaders (Ernst 1998; Heger and Böhmer 2005; Frankow-Lindberg 2012; Wilsey et al. 2015). The composition of the native plant community, however, had a strong impact on the priority effects created by the exotic species on late-arriving natives. When a mixture of native grasses and legumes followed Senecio, these priority effects were nearly $50 \%$ weaker than when legumes were absent from the native community. Although we found evidence for $\mathrm{N}$ sparing in communities containing legumes, as shown by the greater $\mathrm{N}$ content of late-arriving Senecio or grass species when legumes were present (Fig. 6), we cannot fully conclude that the decrease in priority effect strength observed for the grass-legume mixture was solely due to $\mathrm{N}$ facilitation associated with the presence of $\mathrm{N}_{2}$-fixing species in the community, mainly because the two native community compositions used in this study differed in species and functional group richness.

There is now an expanding body of the literature claiming that the creation of priority effects would be a useful technique to restore degraded habitats, alter competitive relationships, and steer plant communities towards desirable states in terms of biodiversity and functioning (Wilsey et al. 2015; Temperton et al. 2016; Weidlich et al. 2017, 2018; Young et al. 2017). Manipulating plant community assembly to promote native species that will ultimately exert strong priority effects on exotics is also a very interesting approach to lower the risk of invasion (Hess et al. 2019). To the best of our knowledge, this study is one of the few that explicitly tested how historical contingency by priority effects impact on the establishment of a rapidly expanding exotic species in European grasslands (Lang et al. 2017). Priority effects being contingent on environmental conditions during plant establishment (Young et al. 2017), their effects on biotic interactions and community structure and functioning are particularly hard to predict, thus presenting a major challenge for plant ecologists. For priority effects to be useful in invasive species management, further research is needed. First, a better understanding of the mechanisms behind the creation of such priority effects is essential for improving the predictive power of ecology. For instance, although niche pre-emption by early-arriving species played a role in our study, we cannot exclude the possibility that other niche modification mechanisms, such as the production of allelochemicals by early-arriving species or plant-soil feedbacks, have occurred. Second, because environmental severity affects the strength of facilitative interactions (Brooker et al. 2007), priority effects (Vannette and Fukami 2014; Young et al. 2017) and invasive success in general (Zefferman et al. 2015), additional experiments are needed to determine how the timing of arrival of Senecio in native grassland communities and facilitative interactions with natives (either direct or indirect) affect invasion across an environmental stress gradient (e.g. disturbance, resource availability). Finally, we argue that long-term experiments 
are needed to elucidate how weather conditions during plant establishment affect the strength, direction, and persistence of priority effects (Temperton et al. 2016).

Altogether, our results have implications for managing the risk of invasion of European grasslands by Senecio inaequidens. The poor establishment of Senecio that we observed when it arrived only three weeks after natives suggests that dense grassland communities are unlikely to be invaded. If a disturbance leading to a significant reduction in native species abundance occurs, however, an early arrival of Senecio is a scenario that could potentially favour invasion. Senecio has indeed many characteristics favouring its invasiveness. Each individual is able to produce a large amount of seeds (between 10,000 and 29,000 achenes) that will be dispersed by wind or animals from short to great distances, thus imposing a high propagule pressure on the local environment (Ernst 1998; López-García and Maillet 2005). These seeds then accumulate in the soil where they can persist for several years, particularly if they are buried and not directly located at the soil surface (López-García and Maillet 2005). Both their high degree of dormancy polymorphism and their capacity to resist frost $\left(-15^{\circ} \mathrm{C}\right)$ contribute to their persistence in the soil seed bank (Ernst 1998). Under favourable conditions, seeds produced by Senecio can germinate quickly and seedlings are known to have high relative growth rates, particularly under non-limiting nitrogen supply (Ernst 1998; López-García and Maillet 2005). As disturbed habitats are usually associated with increased nutrient availability and lower competition pressure from natives, it is probable that all the biological characteristics described above will favour invasion by increasing differences in competitive ability between natives and Senecio. This is especially true if Senecio was already present in or next to the disturbed area because seeds are then likely to be present in the soil seed bank. In this situation, increasing native propagule pressure by sowing fast germinating species would be a very interesting strategy to lower the risk of invasion, although the strength of the priority effect will probably depend on the time difference between the germination of native and exotic species. Overall, minimizing the creation of open spaces and niches for Senecio to arrive early is important to lower the risk of invasion, which could be better achieved in mown rather than grazed grasslands.

Acknowledgements We would like to thank Dr. Thomas Niemeyer (Leuphana University Lüneburg, Germany) for his invaluable help and technical support. Many thanks also to Carolina Levicek for all the time spent on making the plant illustrations used in this paper (you can have a look at her work here: http://carolinalevicek.com/). This research was funded by the Chair of Ecosystem Functioning and Services, Leuphana University Lüneburg, Germany.

Author contribution statement $\mathrm{BD}, \mathrm{EW}$ and VT conceived the ideas and designed methodology; $\mathrm{BD}, \mathrm{EW}$ and $\mathrm{MK}$ performed the experiment; BD, MK and JN collected the data; BD analysed the data and led the writing of the manuscript. All authors contributed critically to the drafts and gave final approval for publication.

Data accessibility Raw data and R scripts used for data analysis are fully accessible here: https://doi.org/10.5281/zenodo.2558204

\section{Compliance with ethical standards}

Conflict of interest The authors declare that they have no conflict of interest.

Statement of human and animal rights This article does not contain any studies with human participants or animals performed by any of the authors.

Open Access This article is distributed under the terms of the Creative Commons Attribution 4.0 International License (http://creativeco mmons.org/licenses/by/4.0/), which permits unrestricted use, distribution, and reproduction in any medium, provided you give appropriate credit to the original author(s) and the source, provide a link to the Creative Commons license, and indicate if changes were made.

\section{References}

Abraham JK, Corbin JD, D'Antonio CM (2009) California native and exotic perennial grasses differ in their response to soil nitrogen, exotic annual grass density, and order of emergence. Plant Ecol 201:445-456. https://doi.org/10.1007/s11258-008-9467-1

Allendorf FW, Lundquist LL (2003) Introduction: population biology, evolution, and control of invasive species. Conserv Biol 17:24-30. https://doi.org/10.1046/j.1523-1739.2003.02365.x

Aschehoug ET, Callaway RM, Newcombe G et al (2014) Fungal endophyte increases the allelopathic effects of an invasive forb. Oecologia 175:285-291. https://doi.org/10.1007/s0044 2-014-2891-0

Bossdorf O, Lipowsky A, Prati D (2008) Selection of preadapted populations allowed Senecio inaequidens to invade Central Europe. Divers Distrib 14:676-685. https://doi.org/10.111 1/j.1472-4642.2008.00471.x

Brooker RW, Maestre FT, Callaway RM et al (2007) Facilitation in plant communities: the past, the present, and the future. J Ecol 96:18-34. https://doi.org/10.1111/j.1365-2745.2007.01295.x

Bruno JF, Stachowicz JJ, Bertness MD (2003) Inclusion of facilitation into ecological theory. Trends Ecol Evol 18:119-125. https://doi. org/10.1016/S0169-5347(02)00045-9

Bulleri F, Bruno JF, Benedetti-Cecchi L (2008) Essay beyond competition: incorporating positive interactions between species to predict ecosystem invasibility. PLoS Biol 6:e162. https://doi.org/10.1371/ journal

Byun C, de Blois S, Brisson J (2013) Plant functional group identity and diversity determine biotic resistance to invasion by an exotic grass. J Ecol 101:128-139. https://doi.org/10.1111/1365-2745.12016

Callaway RM, Aschehoug ET (2000) Invasive plants versus their new and old neighbors: a mechanism for exotic invasion. Science 80(290):521-523. https://doi.org/10.1126/science.290.5491.521

Callaway RM, Ridenour WM (2004) Novel weapons: invasive success and the evolution of increased competitive ability. Front Ecol Environ 2:436-443

Callaway RM, Thelen GC, Rodriguez A, Holben WE (2004) Soil biota and exotic plant invasion. Nature 427:731-733. https://doi. org/10.1038/nature02322 
Chase JM (2003) Community assembly: when should history matter? Oecologia 136:489-498. https://doi.org/10.1007/s0044 2-003-1311-7

Chytrý M, Maskell LC, Pino J et al (2008) Habitat invasions by alien plants: a quantitative comparison among Mediterranean, subcontinental and oceanic regions of Europe. J Appl Ecol 45:448-458. https://doi.org/10.1111/j.1365-2664.2007.01398.x

Cleland EE, Esch E, Mckinney J (2015) Priority effects vary with species identity and origin in an experiment varying the timing of seed arrival. Oikos 124:33-40. https://doi.org/10.1111/oik.01433

Crawley MJ, Brown SL, Heard MS, Edwards GR (1999) Invasionresistance in experimental grassland communities: species richness or species identity? Ecol Lett 2:140-148

Davis MA, Grime JP, Thompson K (2000) Fluctuating resources in plant communities: a general theory of invasibility. J Ecol 88:528 534. https://doi.org/10.1046/j.1365-2745.2000.00473.x

Díaz-Sierra R, Verwijmeren M, Rietkerk M et al (2017) A new family of standardized and symmetric indices for measuring the intensity and importance of plant neighbour effects. Methods Ecol Evol 8:580-591. https://doi.org/10.1111/2041-210X.12706

Dickson TL, Hopwood JL, Wilsey BJ (2012) Do priority effects benefit invasive plants more than native plants? An experiment with six grassland species. Biol Invasions 14:2617-2624. https://doi. org/10.1007/s10530-012-0257-2

Elbakidze M, Hahn T, Zimmermann NE et al (2018) Chapter 4: Direct and indirect drivers of change in biodiversity and nature's contributions to people. In: Rounsevell M, Fischer M, Torre-Marin Rando A, Mader A (eds) The IPBES regional assessment report on biodiversity and ecosystem services for Europe and Central Asia. Secretariat of the Intergovernmental Science-Policy Platform on Biodiversity and Ecosystem services, Bonn, pp 549-809

Ernst WHO (1998) Invasion, dispersal and ecology of the South African neophyte Senecio inaequidens in The Netherlands: from wool alien to railway and road alien

Fargione JE, Tilman D (2005) Diversity decreases invasion via both sampling and complementarity effects. Ecol Lett 8:604-611. https ://doi.org/10.1111/j.1461-0248.2005.00753.x

Fargione J, Brown CS, Tilman D (2004) Community assembly and invasion: an experimental test of neutral versus niche processes. Proc Natl Acad Sci USA 101:8916-8920. https://doi.org/10.1073/ pnas. 1033107100

Flory SL, Bauer JT (2014) Experimental evidence for indirect facilitation among invasive plants. J Ecol 102:12-18. https://doi. org/10.1111/1365-2745.12186

Frankow-Lindberg BE (2012) Grassland plant species diversity decreases invasion by increasing resource use. Oecologia 169:793-802. https://doi.org/10.1007/s00442-011-2230-7

Fukami T (2015) Historical contingency in community assembly: integrating niches, species pools, and priority effects. Annu Rev Ecol Evol Syst 46:1-23. https://doi.org/10.1146/annurev-ecolsys-11041 $1-160340$

Grman E, Suding KN (2010) Within-year soil legacies contribute to strong priority effects of exotics on native California grassland communities. Restor Ecol 18:664-670. https://doi.org/10.1111/ j.1526-100X.2008.00497.x

Heger T, Böhmer HJ (2005) The invasion of Central Europe by Senecio inaequidens DC.- - complex biogeographical problem. Erdkunde 59:34-49. https://doi.org/10.3112/erdkunde.2005.01.03

Hess MCM, Mesléard F, Buisson E (2019) Priority effects: emerging principles for invasive plant species management. Ecol Eng 127:48-57. https://doi.org/10.1016/j.ecoleng.2018.11.011

Hothorn T, Bretz F, Westfall P (2008) Simultaneous inference in general parametric models. Biometrical J 50:346-363

Keane RM, Crawley MJ (2002) Exotic plant invasions and the enemy release hypothesis. Trends Ecol Evol 17:164-170. https://doi. org/10.1016/S0169-5347(02)02499-0
Kennedy TA, Naeem S, Howe KM et al (2002) Biodiversity as a barrier to ecological invasion. Nature 417:636-638. https://doi. org/10.1038/nature00776

Knops JMH, Tilman D, Haddad NM et al (1999) Effects of plant species richness on invasion dynamics, disease outbreaks, insect abundances and diversity. Ecol Lett 2:286-293. https://doi.org/ 10.1046/j.1461-0248.1999.00083.x

Kolar CS, Lodge DM (2001) Progress in invasion biology: predicting invaders. Trends Ecol Evol 16:199-204. https://doi.org/10.1016/ S0169-5347(01)02101-2

Körner C, Stöcklin J, Reuther-Thiébaud L, Pelaez-Riedl S (2008) Small differences in arrival time influence composition and productivity of plant communities. New Phytol 177:698-705. https ://doi.org/10.1111/j.1469-8137.2007.02287.x

Lachmuth S, Durka W, Schurr FM (2010) The making of a rapid plant invader: genetic diversity and differentiation in the native and invaded range of Senecio inaequidens. Mol Ecol 19:39523967. https://doi.org/10.1111/j.1365-294X.2010.04797.x

Lang M, Hanslin HM, Kollmann J, Wagner T (2017) Suppression of an invasive legume by a native grass - High impact of priority effects. Basic Appl Ecol 22:20-27. https://doi.org/10.1016/j. baae.2017.06.005

Levine JM, Adler PB, Yelenik SG (2004) A meta-analysis of biotic resistance to exotic plant invasions. Ecol Lett 7:975-989. https ://doi.org/10.1111/j.1461-0248.2004.00657.x

Liu Y, Zhang X, van Kleunen M (2018) Increases and fluctuations in nutrient availability do not promote dominance of alien plants in synthetic communities of common natives. Funct Ecol 32:25942604. https://doi.org/10.1111/1365-2435.13199

López-García MC, Maillet J (2005) Biological characteristics of an invasive south African species. Biol Invasions 7:181-194. https ://doi.org/10.1007/s 10530-004-8978-5

Maron JL, Connors PG (1996) A native nitrogen-fixing shrub facilitates weed invasion. Oecologia 105:302-312. https://doi. org/10.1007/BF00328732

Martin LM, Wilsey BJ (2012) Assembly history alters alpha and beta diversity, exotic-native proportions and functioning of restored prairie plant communities. J Appl Ecol 49:1436-1445. https:// doi.org/10.1111/j.1365-2664.2012.02202.x

Mason TJ, French K, Jolley D (2013) Arrival order among native plant functional groups does not affect invasibility of constructed dune communities. Oecologia 173:557-568. https:// doi.org/10.1007/s00442-013-2628-5

Mason TJ, French K, Jolley DF (2017) Functional richness and identity do not strongly affect invasibility of constructed dune communities. PLoS ONE 12:e0169243. https://doi.org/10.1371/ journal.pone.0169243

Mwangi PN, Schmitz M, Scherber C et al (2007) Niche preemption increases with species richness in experimental plant communities. J Ecol 95:65-78. https://doi.org/10.111 1/j.1365-2745.2006.01189.x

Naeem S, Knops JMH, Tilman D et al (2000) Plant diversity increases resistance to invasion in the absence of covarying extrinsic factors. Oikos 91:97-108. https://doi.org/10.103 4/j.1600-0706.2000.910108.x

Perkins LB, Hatfield G (2014) Competition, legacy, and priority and the success of three invasive species. Biol Invasions 16:25432550. https://doi.org/10.1007/s10530-014-0684-3

Pokorny ML, Sheley RL, Zabinski CA et al (2005) Plant functional group diversity as a mechanism for invasion resistance. Restor Ecol 13:448-459. https://doi.org/10.1111/j.1526100X.2005.00056.x

Prieur-Richard A-H, Lavorel S, Grigulis K, Dos Santos A (2000) Plant community diversity and invasibility by exotics: invasion of Mediterranean old fields by Conyza bonariensis and 
Conyza canadensis. Ecol Lett 3:412-422. https://doi.org/10.10 46/j.1461-0248.2000.00157.x

Prieur-Richard A-H, Lavorel S, Dos Santos A, Grigulis K (2002) Mechanisms of resistance of Mediterranean annual communities to invasion by Conyza bonariensis: effects of native functional composition. Oikos 99:338-346. https://doi.org/10.103 4/j.1600-0706.2002.990215.x

R Core Team (2018) R: A language and environment for statistical computing. R Foundation for Statistical Computing, Vienna, Austria. URL http://www.r-project.org/

Saccone P, Pagès J-P, Girel J et al (2010) Acer negundo invasion along a successional gradient: early direct facilitation by native pioneers and late indirect facilitation by conspecifics. New Phytol 187:831-842. https://doi.org/10.1111/j.1469-8137.2010.03289.x

Sakai AK, Allendorf FW, Holt JS et al (2001) The Population Biology of Invasive Species. Annu Rev Ecol Syst 32:305-332. https://doi. org/10.1146/annurev.ecolsys.32.081501.114037

Sala OE, Chapin III FS, Armesto JJ, et al (2000) Global Biodiversity Scenarios for the Year 2100. Science (80-) 287:1770-1774. https ://doi.org/10.1126/science.287.5459.1770

Scherber C, Crawley MJ, Porembski S (2003) The effects of herbivory and competition on the invasive alien plant Senecio inaequidens (Asteraceae). Divers Distrib 9:415-426. https://doi.org/10.104 6/j.1472-4642.2003.00049.x

Scherber C, Mwangi PN, Schmitz M et al (2010) Biodiversity and belowground interactions mediate community invasion resistance against a tall herb invader. J Plant Ecol 3:99-108. https:// doi.org/10.1093/jpe/rtq003

Seastedt TR, Pyšek P (2011) Mechanisms of Plant Invasions of North American and European Grasslands. Annu Rev Ecol Evol Syst 42:133-153. https://doi.org/10.1146/annurev-ecolsys-10271 $0-145057$

Shea K, Chesson P (2002) Community ecology theory as a framework for biological invasions. Trends Ecol Evol 17:170-176. https:// doi.org/10.1016/S0169-5347(02)02495-3

Simberloff D, Von Holle B (1999) Positive Interactions of Nonindigenous Species: invasional Meltdown? Biol Invasions 1:21-32. https://doi.org/10.1023/A:1010086329619

Stevens JM, Fehmi JS (2011) Early establishment of a native grass reduces the competitive effect of a non-native grass. Restor Ecol 19:399-406. https://doi.org/10.1111/j.1526-100X.2009.00565.x

Stuble KL, Souza L (2016) Priority effects: natives, but not exotics, pay to arrive late. J Ecol 104:987-993. https://doi. org/10.1111/1365-2745.12583

Suding KN, Harpole WS, Fukami T et al (2013) Consequences of plant-soil feedbacks in invasion. J Ecol 101:298-308. https://doi. org/10.1111/1365-2745.12057

Temperton VM, Mwangi PN, Scherer-Lorenzen M et al (2007) Positive interactions between nitrogen-fixing legumes and four different neighbouring species in a biodiversity experiment. Oecologia 151:190-205. https://doi.org/10.1007/s00442-006-0576-Z

Temperton VM, Baasch A, von Gillhaussen P, Kirmer A (2016) Assembly theory for restoring ecosystem structure and functioning: timing is everything? In: Palmer MA, Zedler JB, Falk DA (eds) Foundations of Restoration Ecology. Island Press, Second Edi, pp 245-270

Tilman D (1997) Community invasibility, recruitment limitation, and grassland biodiversity. Ecology 78:81-92. https://doi. org/10.1890/0012-9658(1997)078\%5b0081:cirlag\%5d2.0.co;2
Ulrich E, Perkins L (2014) Bromus inermis and Elymus canadensis but not Poa pratensis demonstrate strong competitive effects and all benefit from priority. Plant Ecol 215:1269-1275. https://doi. org/10.1007/s11258-014-0385-0

Unkovich M, Herridge D, Peoples M, et al (2008) Measuring plantassociated nitrogen fixation in agricultural systems

van der Putten WH, Bardgett RD, Bever JD et al (2013) Plant-soil feedbacks: the past, the present and future challenges. J Ecol 101:265-276. https://doi.org/10.1111/1365-2745.12054

Vannette RL, Fukami T (2014) Historical contingency in species interactions: towards niche-based predictions. Ecol Lett 17:115-124. https://doi.org/10.1111/ele.12204

Vaughn KJ, Young TP (2015) Short-term priority over exotic annuals increases the initial density and longer-term cover of native perennial grasses. Ecol Appl 25:791-799. https://doi. org/10.1890/14-0922.1

von Gillhaussen P, Rascher U, Jablonowski ND et al (2014) Priority effects of time of arrival of plant functional groups override sowing interval or density effects: a grassland experiment. PLoS ONE 9:e86906. https://doi.org/10.1371/journal.pone.0086906

Wainwright CE, Cleland EE (2013) Exotic species display greater germination plasticity and higher germination rates than native species across multiple cues. Biol Invasions 15:2253-2264. https ://doi.org/10.1007/s10530-013-0449-4

Wainwright CE, Wolkovich EM, Cleland EE (2012) Seasonal priority effects: implications for invasion and restoration in a semiarid system. J Appl Ecol 49:234-241. https://doi.org/10.111 1/j.1365-2664.2011.02088.x

Wardle DA (2001) Experimental demonstration that plant diversity reduces invasibility - evidence of a biological mechanism or a consequence of sampling effect? Oikos 95:161-170. https://doi. org/10.1034/j.1600-0706.2001.950119.x

Wardle DA, Bardgett RD, Callaway RM, van der Putten WH (2011) Terrestrial ecosystem responses to species gains and losses. Science (80-) 332:1273-1277. https://doi.org/10.1126/science.11974 79

Weidlich EWA, von Gillhaussen P, Delory BM et al (2017) The importance of being first: exploring priority and diversity effects in a grassland field experiment. Front Plant Sci 7:1-12. https://doi. org/10.3389/fpls.2016.02008

Weidlich EWA, von Gillhaussen P, Max JFJ et al (2018) Priority effects caused by plant order of arrival affect belowground productivity. J Ecol 106:774-780. https://doi.org/10.1111/1365-2745.12829

Wilsey BJ, Barber K, Martin LM (2015) Exotic grassland species have stronger priority effects than natives regardless of whether they are cultivated or wild genotypes. New Phytol 205:928-937. https ://doi.org/10.1111/nph.13028

Yannelli FA, Koch C, Jeschke JM, Kollmann J (2017) Limiting similarity and Darwin's naturalization hypothesis: understanding the drivers of biotic resistance against invasive plant species. Oecologia 183:775-784. https://doi.org/10.1007/s00442-016-3798-8

Young TP, Stuble KL, Balachowski JA, Werner CM (2017) Using priority effects to manipulate competitive relationships in restoration. Restor Ecol 25:S114-S123. https://doi.org/10.1111/rec.12384

Zefferman E, Stevens JT, Charles GK et al (2015) Plant communities in harsh sites are less invaded: a summary of observations and proposed explanations. AoB Plants 7:plv056. https://doi.org/10.1093/ aobpla/plv056 